\title{
Susceptibility Test of Staphylococcus aureus Isolated from Cow Milk, Goat Milk, and Dairy Farm Workers Against Various Antibiotics
}

\author{
C M Santosa ${ }^{1}$, N P Rukmi ${ }^{1}$, F B Lestari ${ }^{2}$, M Wasissa ${ }^{1}$, D A \\ Dewananda ${ }^{1}$, \\ S I O Salasia ${ }^{1, *}$ \\ ${ }^{1}$ Faculty of Veterinary Medicine, Universitas Gadjah Mada, Jl. Fauna 2, Karangmalang, Yogyakarta 55281, \\ Indonesia \\ ${ }^{2}$ UGM Vocational College, Universitas Gadjah Mada, Sekip Unit I, Yogyakarta 55281, Indonesia \\ *Corresponding author, E-mail: isrinasalasia@ugm.ac.id
}

\begin{abstract}
Staphylococcus aureus is a Gram-positive bacteria causing pneumonia, mastitis, meningitis, and urinary tract infections. The emergence of Methicillin-Resistant Staphylococcus aureus (MRSA) as a highly pathogenic strain caused a health problem that needed more attention in both human and animal medicine. This research aimed to determine the type of antibiotic that was appropriate and effective in treating diseases caused by bacteria in animals and humans. The susceptibility test was carried out by the diffusion method using Mueller Hinton Agar (MHA) and against seven various antibiotic discs. The samples used for this test were 18 Staphylococcus aureus isolated from cow and goat's milk and a nasal swab of a dairy farmworker. The results of the measured resistance zone formed were interpreted with a standard interpretation table of the Kirby-Bauer. The results showed that 18 Staphylococcus aureus isolates were resistant to ampicillin (100\%), oxacillin (83,33\%), penicillin-G $(100 \%)$, tetracycline $(72.22 \%)$. The isolates showed intermediate susceptibility to erythromycin $(61.11 \%)$, oxacillin $(5,56 \%)$, and sensitivity to gentamicin $(100 \%)$, cefoxitin $(77.78 \%)$, and oxacillin $(11,11 \%)$. It was concluded that gentamicin and cefoxitin were still effective in treating diseases caused by Staphylococcus aureus.
\end{abstract}

Keywords: Staphylococcus aureus, Susceptibility test, antibiotics.

\section{INTRODUCTION}

Methicillin-Resistant Staphylococcus aureus (MRSA) infection became one of the most concerning health problems due to its highly pathogenic characteristics. The bacteria are known to be able to grow even after exposure to different concentrations of antibiotics, which are usually enough to kill normal Staphylococcus aureus. As a result, the treatment of MRSA and other bacteria that are resistant to antibiotics were usually not as effective and often failed [1]. According to the World Health Organization (WHO), antimicrobial resistance has the potential to affect all people of all ages from many countries in 2014. World Health Organization also had launched the World Antibiotic Awareness Week in 2018 after several breakthroughs have been carried out in the past ten years. Staphylococcus aureus is a Gram-positive bacteria causing severe cases of infection, including pneumonia, mastitis, meningitis, and urinary tract infections [2]. This study aimed to determine the types of antibiotics that are appropriate and effective in dealing with diseases caused by Staphylococcus aureus infections in both humans and animals in Indonesia.

\section{METHOD}

The samples used for this test were 18 Staphylococcus aureus isolated from milk cows, milk goats, and a nasal swab of a dairy farmworker in Cangkringan and Turi Village, Sleman Regency, Jogjakarta. Isolation and identification of Staphylococcus aureus were carried out at the Health and Calibration Laboratory Center, Jogjakarta. Thirteen milk samples of cows, four samples of goats, and 1 sample of a nasal swab from dairy workers were identified as Staphylococcus aureus. The susceptibility test was 
carried out by the diffusion method using Mueller Hinton Agar (MHA) against seven various antibiotic discs [3]. The culture of Staphylococcus aureus was dropped onto the surface of MHA and flattened using a glass spreader [4]. The bacterial sensitivity test was carried out by measuring the resistance zone formed after 18-24 hours. The results measured from the resistance zone formed were interpreted with a standard interpretation table of the Kirby-Bauer. There were three interpretations of the measurement results, those being resistant, intermediate, and sensitive to antibiotics [5, 6].

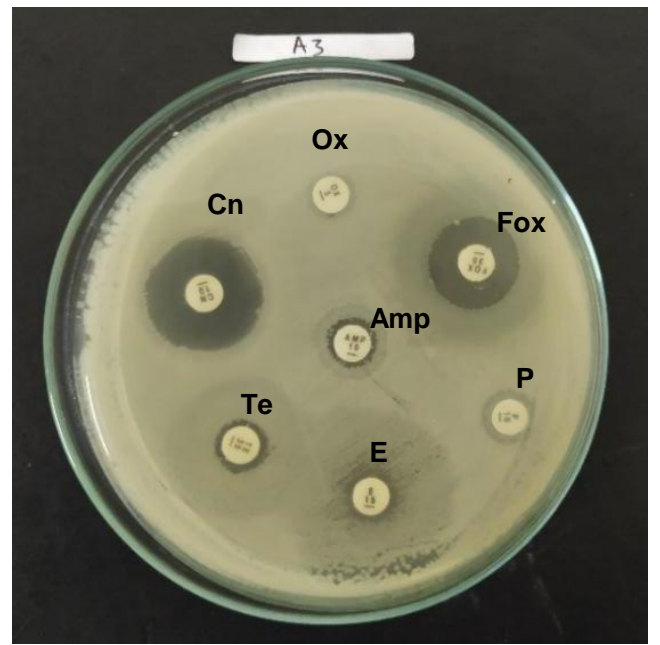

Figure 1. Sensitivity test of A3 Staphylococcus aureus isolate against ampicillin (Amp), oxacillin (Ox), gentamicin $(\mathrm{Cn})$, tetracycline (Te), erythromycin (E), penicillin $\mathrm{G}(\mathrm{P})$, and cefoxitin (Fox)

Figure 1 (isolate A3) reveals the Staphylococcus aureus sensitivity test from milk cow against seven types of antibiotics. The results showed sensitivity to gentamicin, which diameter of $19 \mathrm{~mm}$ inhibition zone. Against erythromycin, A3 isolates had intermediate susceptibility with a width of inhibition zone $17 \mathrm{~mm}$. This A3 isolate was also resistant to ampicillin, oxacillin, tetracycline, erythromycin, penicillin $\mathrm{G}$, and cefoxitin. The inhibition zones produced were $8 \mathrm{~mm}, 6 \mathrm{~mm}, 9$ $\mathrm{mm}, 6 \mathrm{~mm}, 6 \mathrm{~mm}$, and $15 \mathrm{~mm}$, respectively. 1.

\section{DISCUSSION}

A sensitivity test was carried out on 18 isolates of Staphylococcus aureus against seven types of antibiotics. The antibiotics used were ampicillin (10 $\mu \mathrm{g})$, oxacillin $(5 \mu \mathrm{g})$, gentamicin $(10 \mu \mathrm{g})$, tetracycline $(30 \mu \mathrm{g})$, erythromycin $(15 \mu \mathrm{g})$, penicillin $\mathrm{G}(10 \mu \mathrm{g})$, and cefoxitin $(30 \mu \mathrm{g})$. The sensitivity test produced diameter of the inhibition zone $(\mathrm{mm})$ that varies on each isolates. Antibioticsensitive bacteria show bright zones, while the resistant ones did not produce bright zones around antibiotic discs. The light formed zones on each antibiotic for each isolate was measured in units of millimeters ( $\mathrm{mm}$ ) and compared to the standard interpretation table of the Kirby-Bauer Inhibitory Zone.

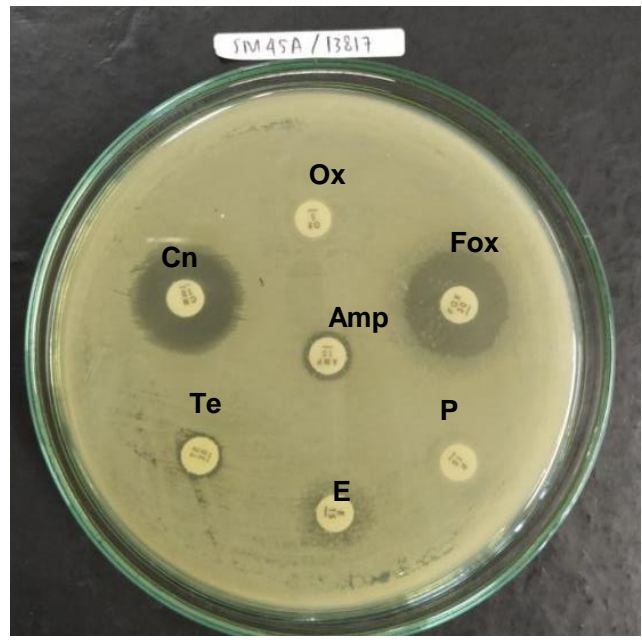

Figure 2. Sensitivity test of SM $45 \mathrm{~A} / 13817$ Staphylococcus aureus isolates against ampicillin (Amp), oxacillin (Ox), gentamicin $(\mathrm{Cn})$, tetracycline $(\mathrm{Te})$, erythromycin $(\mathrm{E})$, penicillin $\mathrm{G}(\mathrm{P})$, and cefoxitin (Fox)

The Staphylococcus aureus isolated from goats (SM 45A/13817) showed sensitivity against gentamicin and cefoxitin. These isolates were also resistant to ampicillin, oxacillin, tetracycline, erythromycin, and penicillin (Figure 2). Based on these results, A3 and SM 45A/13817 isolates were suspected as MRSA strains based on their resistance to several antibiotics. The resistance of Staphylococcus aureus isolated from cows, goats, and human against several antibiotics are presented, as shown in Table 
Table 1. Distribution of the resistance of Staphylococcus aureus isolated from cows, goats and human against ampicillin, oxacillin, gentamicin, tetracycline, erythromycin, penicillin $\mathrm{G}$, and cefoxitin

\begin{tabular}{cccccccc}
\hline \multirow{2}{*}{ Antibiotic } & \multicolumn{3}{c}{ Sensitive } & & \multicolumn{3}{c}{ Resistant } \\
\cline { 2 - 3 } \cline { 7 - 8 } & $\begin{array}{c}\text { Cow } \\
(\mathrm{n}=13)\end{array}$ & $\begin{array}{c}\text { Goat } \\
(\mathrm{n}=4)\end{array}$ & $\begin{array}{c}\text { Human } \\
(\mathrm{n}=1)\end{array}$ & & $\begin{array}{c}\text { Cow } \\
(\mathrm{n}=13)\end{array}$ & $\begin{array}{c}\text { Goat } \\
(\mathrm{n}=4)\end{array}$ & $\begin{array}{c}\text { Human } \\
(\mathrm{n}=1)\end{array}$ \\
\hline Ampicillin $(10 \mu \mathrm{g})$ & 0 & 0 & 0 & & 13 & 4 & 1 \\
& $(0 \%)$ & $(0 \%)$ & $(0 \%)$ & & $(100 \%)$ & $(100 \%)$ & $(100 \%)$ \\
Oxacillin $(5 \mu \mathrm{g})$ & 1 & 1 & 0 & & 11 & 3 & 1 \\
& $(7,70 \%)$ & $(25 \%)$ & $(0 \%)$ & & $(84,61 \%)$ & $(75 \%)$ & $(100 \%)$ \\
Gentamicin $(10 \mu \mathrm{g})$ & 13 & 4 & 1 & & 0 & 0 & 0 \\
Tetracycline $(30 \mu \mathrm{g})$ & $(100 \%)$ & $(100 \%)$ & $(100 \%)$ & & $(0 \%)$ & $(0 \%)$ & $(0 \%)$ \\
& $(7,70 \%)$ & $(0 \%)$ & $(0 \%)$ & & $(61,54 \%)$ & $(100 \%)$ & $(100 \%)$ \\
Erithromycin $(15 \mu \mathrm{g})$ & 0 & 0 & 0 & & 5 & 1 & 1 \\
Penicillin $\mathrm{G}(10 \mu \mathrm{g})$ & $(0 \%)$ & $(0 \%)$ & $(0 \%)$ & & $(38,46 \%)$ & $(25 \%)$ & $(100 \%)$ \\
& 0 & 0 & 0 & & 13 & 4 & 1 \\
Cefoxitin $(30 \mu \mathrm{g})$ & $(0 \%)$ & $(0 \%)$ & $(0 \%)$ & & $(100 \%)$ & $(100 \%)$ & $(100 \%)$ \\
& $(76,92 \%)$ & $(75 \%)$ & $(100 \%)$ & & $(23,08 \%)$ & $(25 \%)$ & $(0 \%)$ \\
\hline
\end{tabular}

Multi resistance to antibiotics were found in 18 Staphylococcus aureus isolates from cows, goats, and human. Staphylococcus aureus resistance to ampicillin and penicillin showed the highest resistance level of $100 \%$, followed by tetracycline (61.54\% cows, $100 \%$ goats, $100 \%$ human), and oxacillin (61\% cows, $75 \%$ goats, $100 \%$ humans). The resistance of Staphylococcus aureus isolates to erythromycin was not too high $(38.46 \%$ cows, $25 \%$ goats, $100 \%$ human). However, an intermediate level of resistance interpretation was dominant. The resistance of Staphylococcus aureus isolates to cefoxitin $(30 \mu \mathrm{g})$ was very low (cows 23.08\%, goats 25\%, human 0\%). All 18 Staphylococcus aureus isolates from cows, goats, and humans were still sensitive to gentamicin.

Previous research showed that the antibiotics resistance of Staphylococcus aureus isolated from milk cows was $76.92 \%$, milk goats $(41,67 \%)$, and human isolates (80\%) [7, 8]. Research in Egypt [9] reported that $100 \%$ Staphylococcus aureus isolated from cows and bufallows were resistant to ampicillin and oxacillin and suspected as MRSA.

\section{CONCLUSION}

Gentamicin and cefoxitin were still effective in treating diseases caused by Staphylococcus aureus infection.

\section{REFERENCES}

[1] Smith R D and Coast J 2012 The Economic Burden of Antimicrobial Resistance
Among the isolates, $84.8 \%$ Staphylococcus aureus were resistant to ampicillin, and $74.1 \%$ resistant to oxacillin.

According to Drcila and Perlin [10], the mechanism of resistance of microorganisms to antibiotics can occur by destroying antibiotics with enzymes produced by bacteria, changing the capture point receptors on antibiotics, changing the physicochemical properties of antibiotic targets in bacterial cells, changing the properties of bacterial cell walls so that antibiotics cannot penetrate the bacterial wall. According to Navyanti and Adriyani [11], it is crucial to maintain the safety, sanitation, and quality of dairy products, to avoid contamination of bacterial. Bacterial growth in dairy products can be prevented in several ways, such as maintaining and protecting the health of each dairy farm worker and its cows, milk sanitation such as protection against contamination during processing, serving and storage, cleaning of equipment or containers, and control of the environment.

London School of Hygiene and Tropical Medicine

[2] Bisht R, Katiyar A, Sing R, and Mittal P 2009 Antibiotic Resistance - A Global Issue of Concern Asian Journal of Pharmaceutical and Clinical Research Volume 2, Issue 2, April-June, 34-39

[3] Leboffe M J and B E Pierce 2011 A Photographic Atlas for the Microbiology 
Laboratory 4th Edition USA Morton Publishing Company

[4] Srivastava L M 2003 Plant Growth and Development, Hormones and the Environment. Oxford Academic Press

[5] Bauer A W, Kirby M M, Sherris J C, and Tirck M 1996 Antibiotic Susceptibility Testing by a Standardized Single Disk Method The America Journal of Clinical Pathology. 45(1) 493-496

[6] Markey B, Leonard F, Archambault M, Cullinane A, and Maguire D 2013 Clinical Veterinary Microbiology Second Edition Irlandia Mosby Elsevier

[7] Salasia S I O, Tato S, Sugiyono N, Ariyanti D, and Prabawati F 2011 Genotypic Characterization of Staphylococcus aureus isolated from bovines, human, and food in Indonesia

[8] Widianingrum D C, Windria S, and Salasia S I O 2016 Antibiotic Resistance and Methicillin Resistant Staphylococcus aureus Isolated from Bovine Crossbred Etawa Goat and Human Asian Journal of Animal and Veterinary Advances 11 (2) 122-129 2016 ISSN 1683-9919

[9] Elkenany R M 2018 Genetic Characterization of Enterotoxigenic Strains of Methicillin-Resistant and Susceptible Staphylococcus aureus Recovered from Bovine Mastitis Asian Journal of Biological Sciences 11 (1) 18, 2018. ISSN 1996-3351

[10] Drlica K and Perlin D S 2011 Antibiotic Resistance Understanding and Responding to an Emerging Crisis New Jersey F T Press.

[11] Navyanti F and Adriyani R 2015 Higiene Sanitasi, Kualitas Fisik, dan Bakteriologi Susu Sapi Segar Perusahaan Susu X di Surabaya Jurnal Kesehatan Lingkungan 8 (1) 36-47. 